\title{
Reconceptualising the Muslim neighbourhood: claims for space, identity and citizenship in the West
}

\author{
Noha Nasser ${ }^{1}$ \\ Published online: 5 October 2015 \\ (C) Springer Science+Business Media Dordrecht 2015
}

The contemporary Western city has emerged as a new post-colonial frontier in which intense everyday social and cultural encounters have disrupted the purist homogeneous notions of the nation state and with it the notion of a shared community and culture as the basis of citizenship. At the level of the neighbourhood, settled migrant cultures have struggled to make claims to inhabit the city and for recognition of their histories and identities (Holston and Appadurai 1996).

For large numbers of Muslim migrants to the contemporary Western city, the lived experience of displacement and re-territorialisation as a spatial practice remains understudied. Indeed, mainstream depictions of Muslim neighbourhoods still conform to contemporary narratives of the multicultural city. Narratives that are rooted in the deterministic and over-simplified urban ecology model of ethnic enclave, slum, and ghetto in which deprivation, urban degeneration and race conveniently converge. This urban model maintains the status quo of exclusionary spatial practices where the frontier between West and non-West become bounded by clearly defined boundaries (Sayyid 2003).

Since the 1990s there has been a growing recognition in the social sciences of the disruptive politics of difference that is challenging these fixed hierarchical notions of who belongs and who doesn't, which spaces they occupy and which spaces they don't (Jacobs 1996; Zukin 1996; Sandercock 1997; Fincher and Jacobs 1998). As Jacobs $(1993,827)$ notes the city as an object of analysis is now open to the distinctive approaches of a range of interconnected disciplines within the social sciences including geography, urban planning, cultural and feminist studies. Indeed, in this theme issue, authors weave together architecture, urban planning, social and urban geography, ethnography, sociology and history to understanding these disruptions through the process of territorialisation of urban space, and its symbolic and visual expressions of identity. Authors engage in a Muslim ethnography of neighbourhoods that reveal the

Noha Nasser

N.nasser@kingston.ac.uk

1 School of Architecture and Landscape, Kingston University, Knights Park, Kingston KT1 2QJ, UK 
sense of place and cultural meaning; the social construction of urban identity; and the nature of territory, boundaries and frontiers in the city where they experience the everyday.

The significance of this Guest issue stems from an international Symposium, 'Reorienting Diverse Space: neighbourhoods, identity and citizenship' presented by the Centre for Muslim and non-Muslim Understanding at the University of South Australia in 2012 in which a wider enquiry into the perceived problematic relationship between Islam and democracy raised questions about the very premise of Western-style democracy in the context of colonialism and racism. The wider enquiry sought to deconstruct the axiomatic relationship between the West and democracy, and in so doing, to enquire into the different paths and types of democracy (Sayyid 2014). The symposium aimed to examine how Islam and Muslim migrant settlers are contesting the very basis of Western democracy and challenging the hypocrises of the purported ideology of universal equality and respect in the face of visible, overt racism and Islamophobia (Al-Sayyad and Castells 2002). At the scale of the city in the West, Muslims are expanding and eroding the rules, meanings and practices of citizenship in reaction to the universalising rhetoric of who belongs, and who does not, to the nation state.

In this issue a number of common themes emerge as part of this enquiry into the ways in which Muslims are challenging their citizenship rights and claims to the Western City. The first theme is the strategies which have allowed Muslims to make claims for land, buildings and spaces for themselves within a marginal historical, political and spatial position of colonial and post-colonial Western democracies. In her paper on 'Building identity in the Colonial City: The case of the Adelaide Mosque' Bartsch acknowledges the largely unrecognised history of the indispensable role of the Muslim cameleers, known as 'Afghans', in the exploration, discovery and settlement of the Australian desert interior. In her narrative, Bartsch demonstrates the challenges facing the Afghan cameleers in financing and building their first mosque within the 'territorialisation of colonial Adelaide's urban space and hierarchical notions of belonging'. Dominated by the largely Anglo-Saxon, Protestant buildings of the early pioneers, the Afghans, along with the Catholics, occupied a peripheral position on the city fringe. Bartsch carefully crafts biographical accounts of the Afghan pioneers who inspired the construction and purchase of the land to build the Adelaide mosque and describes their endeavours in the face of being 'ostracised from white civilised British space'. The design response was a modest building that blended in to the existing urban fabric using the local vernacular. Bartsch attributes the success of the building of the mosque to the coinciding of a significant economic recession when there was a pressing need to fill the city coffers. Fortunately, the marginal location also allowed for more visible markers to be constructed, such as the four minarets built a few years later, and the extant brick wall 'interpreted as a means to distance the Muslim faithful from the surrounding neighbourhood'. In conclusion, Bartsch argues that 'the agency of the cameleers that provided the funds, their extraordinary contributions to the development of the inland economy, and by extension the fortunes of the colonial city complicates the patterns of the settler-colony city' with the overlapping territories and intertwined histories that do not neatly map onto the model of centre and periphery. The spatial history of the Muslim cameleers is one of persistence and collective solidarity to create a space they can call their own within an unwelcoming colonial Australian territory. 
In the same theme, my paper 'Patronage and territoriality: Islamising Space in the Western City', the comparative study of three mosques in Adelaide built during the colonial and post-colonial periods represents contested spaces. I argue the Adelaide mosque was built within the least desirable southwest quarter of the City of Adelaide, an area of light industry, and located mid-block, was a form of spatially managing undesirable minorities by building out of visible sight from the main roads. This peripheral positioning to some degree suited the Afghans whose primary aim was to provide a safe space that represented their religious, educational and pastoral community needs, and an expression of their identity as a very small community within a largely Christian colonial urban landscape. With the onset of large scale post second world war migration, and the constitution of the first Muslim collective, the Islamic Society of South Australia (ISSA), buildings were purchased through the legal vehicle of an urban incorporation to overcome contestations. The Omar Bin AlKhattab mosque, located on a visible road in the suburbs, did not at first draw attention because Muslims used the disused church on the site. However, with plans to redevelop the site with a more visual and symbolic representation of mosque aesthetics, local neighbours disputed the plans and generated a negative media campaign to prevent the mosque from being built. Fortunately the long-standing good relations with the local Council eventually consented to the mosque re-development. In the third case study of AlKhalil Mosque and Islamic Centre, the Trustee of the charitable endowment trust chose to locate the mosque in a peripheral designated industrial zone to avoid attracting controversy during a time when Islamophobia was rife, therefore, creatively circumventing opposition to realise his ambition to create a centre for culture and learning, as well as the provision of a dedicated Muslim burial site. In this paper, I conclude that in the three case studies, Muslims were mobilised into collective action to build a mosque, and through processes of challenging and adapting to the political context, as well as through negotiated relations with the dominant culture, they succeeded in making those claims for city land to realise their ambitions.

In her paper, 'The Transformation of Place in Regent Park, Toronto', Jamil describes the aspirational public housing project of Regent Park modelled on the 'Garden City' which attracted large numbers of Muslim residents and very soon after its construction in the 1940s became branded an inner-city ghetto. Marginalised socially and economically, the physical environment was neglected, laying the ground for large scale urban intervention through the Regent Park Revitalization Plan. Under this pretext, the large Muslim resident population was decanted out of the area and in the process the Muslims experienced a sense of loss of belonging. Jamil uses detailed ethnographic narratives to trace the meaning of Regent Park to local Muslims and the opposing narratives of place between the residents and the developers Daniels Corporation. These opposing narratives are tangibly exemplified in the making of The Quilt by a group of Bengali women that combined meaningful landmarks of Regent Park with stories and memories of their sense of belonging in the neighbourhood. Jamil's paper shows how the 'official' narratives of the new Regent Park replaces the significance of Muslim settlement with a new 'multicultural narrative of Toronto, and by association Canada, without acknowledging the deeper emotional effects of the changes in Regent Park'. Jamil concludes that a place like Regent Park has multiple narratives, however, the notion of a 'Muslim place' is founded in 'the social and psychological meaning that its Muslim residents invest in it, and the value they give to living there, raising their 
children there, alongside their neighbours and friends, both Muslim and non-Muslim'. Therefore, within the pluralities of place that give meaning and significance to Regent Park as a community and a neighbourhood, the Muslim's narratives of Regent Park are given legitimacy through the making of The Quilt as a visual symbol of their unique attachment to that place.

The second common theme that has emerged is the role of the media in producing and reproducing Muslim stereotypes to reinforce social and cultural hierarchies in the contemporary context. The papers in this issue demonstrate that in spite of the metanarratives that construct anti-Muslim sentiment, at the level of human relations Muslims have created a sense of belonging and bridged across cultural divides. Kabir's paper, 'The Cronulla Riots: Muslims' place in the white imaginary spatiality' describes the media 'beat-up' in the tabloid press and talkback radio that enflamed anti-Muslim attitudes after the riots on Cronulla Beach between Lebanese Australians and AngloAustralians. Kabir examines the spatial politics of the iconic status of the beach in the Australian national imaginary as a 'white' national space. By analysing the media reporting of the incident, Kabir draws evidence of the collapsing of narratives of 'Lebanese Muslims' and 'criminality' to construct a stereotype for cultural exclusion. She describes the way in which media stereotyping is deeply intertwined in the violent attacks that were played out on the beach, what Kabir terms the spatial exclusion of Lebanese Muslims from 'the white imaginary spatiality'. In a series of interviews with Lebanese youth, Kabir demonstrates their strong sense of belonging to Australia and their strong claims for the use of public spaces such as Cronulla beach. According to Kabir, the Cronulla riots were a defining moment in the construction of 'Australianess' and the racism of white supremacy played out spatially in Australia's iconic beaches.

In my paper, I demonstrate the recognised legitimacy of the Afghans, the Islamic Society of South Australia, and Fathi Shahin lay in the nature of their relations with the dominant culture. In the case of the Afghans, three factors gave them limited recognition; the close connections with the outback pioneers; the economic contribution and business relations in the trading of camels; and the intermarrying with Anglo-Australian women. The collective solidarity of the Islamic Society of South Australia was an important factor in defining ethnic boundaries within the dominant context, but at the same time gave them a stronger voice in raising their concerns and making demands of local government. This is best exemplified in the case of the Omar Bin AlKhattab mosque redevelopment. The media frenzy that the mosque generated under the fear of radicalism as a result of the mosque leader's transnational connections with the Middle East, was indicative of a period of Islamophobia and mistrust between different cultures. However, the longstanding personal relations with local government, and the Mayor of Marion Council in particular, assisted ISSA in achieving planning permission. In the case of Fathi Shahin, trustee of the Al-Khalil Mosque, his legitimacy was borne out of his rise to influential business leader and carrier of a moderate form of Islam, more palpable to the dominant culture. By virtue of his economic status, Shahin's social position within South Australian society was one of respect and admiration allowing him access to the political network. His mosque, although marginally located, received much less contestation because of the negotiated careful positioning of Muslim space within the city.

In Jamil's paper the developers of Regent Park, The Daniels Corporation, construct their new narratives of the place as a multicultural place with only a cursory recognition 
of the residents who have lived there for decades. This is demonstrated in developer's response to The Quilt designed and created by Bengali women of their memories of Regent Park's landmarks. Jamil analyses how The Quilt is utilised as a symbol for the developer's commitment to 'work with the community', however, the developers divert attention to it's composition of the style, colour and expression of the place as less a story about belonging, and more one of representing the richness and diversity of Regent Park and Toronto as a whole. Jamil argues The Quilt is used as an object in the production of Regent Park as a place in the 'official' external narrative. However, through the insightful interviews with the Bengali women, Jamil demonstrates the discrepancy between the internal narratives of meaning and sense of belonging, and the external narrative aimed at 'packaging' Regent Park to a wider commercial market.

The third and final common theme is the strategies for Muslim collective identity construction and the defining of an ethnic boundary as a means of mobilising collective action and resources. In Bartsch's paper, her biographical accounts of the Afghan pioneers draws a picture of enterprising individuals with highly desirable skills. One cameleer in particular stands out. Bejah Dervish is depicted by his European master as an excellent camel man, drawing media attention to their exploits. A number of other successful cameleers are described demonstrating that although they would have been considered indentured labour, they were able to earn. It is with these savings that the Adelaide Mosque was funded through collections, and the significant leadership of Mullah Merban and Abdul Wahid (the former a spiritually and the latter economically). As influential partners amongst the cameleers they worked to purchase the land, commission and build the Adelaide Mosque. In defining their collective identity, Bartsch argues that the hybrid architectural expression of the small mosque represented the lowkey approach of the time to 'fit in' with a primary focus on the local needs of the community, and a locus of community life, prayer, education and gathering.

In my paper, I agree with Bartsch that the low visual impact of the Adelaide mosque and the use of local vernacular materials and building traditions represents the assimilationist expectations of the time. In the post-colonial period, however, there are two distinctive approaches to Muslim collective identity construction. The first is exemplified in the creation of the Islamic Society for South Australia in the earlier period of mass migration in which small fragmented Muslim social groups from diverse ethnic and national origins develop a solidarity to construct a mosque as a representation of the faith and the Ummah (the global Muslim fellowship). In this instance, the coalescing around a common goal for shared use is the primary mobiliser for sharing resources and constructing a unified identity. At first, this identity may not have been visually expressed as in the case of the Omar Bin AlKhattab mosque that was based on adapting the spaces of an existing church. However, in the later phase of redevelopment the visual expression was fundamentally connected with Middle Eastern stylistic interpretations of a purer, more authentic, form of Islam. The second approach is the consolidation of multiple forms of Muslim identity construction according to ethnic and national origin. In this scenario, the AlKhalil mosque draws it visual precedents from Palestine following the founders homeland experience, however the building is diluted in scale and street presence so as not to draw unnecessary attention. In this case, Muslim identity is more fragmented in its representation of the different smaller Muslim groupings. 
In Kabir's paper, Cronulla beach is the disputed territory and boundary between 'us' and 'them'. The presence of Anglo-Australian bodies draped in the Australian flag and the opposing Lebanese Australians in the same space are the identity markers that define collective identity construction and ethnic boundary making. In this case, access and claims to the use of the beach as a shared space is the focus of contestation. Similarly in Jamil's paper the contested space is the Regent Park public housing development. In this case, the presence of a large Muslim resident population has defined certain landmarks and spaces that connect the Muslim community together. However, with the Revitalisation Plan, these spaces have been replaced with wider notions of multiculturalism, in effect changing the ethnic boundary from one defined as Muslim to that of forced de-Islamising through redevelopment and displacement.

In conclusion, this theme issue presents a broad range of case studies and interdisciplinary methods of analysing the claims of space, identity and citizenship in the making of Muslim space. The focus on the lived experience of Muslims through ethnographic accounts as well as archival reconstructions sheds a new light on the strategies by which Muslims have demanded their own spaces in the Western city and challenged exclusionary spatial practices by redefining their rights and basis to citizenship.

\section{References}

Al-Sayyad, N., \& Castells, M. (2002). Muslim Europe or Euro-Islam: Politics, culture, and citizenship in the age of globalization (Transnational perspectives on space and place). New York: Lexington Books.

Fincher, R., \& Jacobs, J. M. (Eds.). (1998). Cities of difference. Guildford: Guildford Press.

Holston, J., \& Appadurai, A. (1996). Cities and citizenship. Public Culture, 8(2), 187-204.

Jacobs, J. M. (1996). Edge of empire: Postcolonialism and the city. London: Routledge.

Jacobs, J. M. (1993). The City Unbound: Qualitative Approaches to the City. Urban Studies, 30(4-5), 827-848. Sandercock, L. (1997). Towards Cosmopolis. Planning for multicultural cities. Chichester: Wiley.

Sayyid, S. (2003). A fundamental fear: Eurocentrism and the emergence of Islamism. London: Zed Books. Sayyid, S. (2014). Recalling the caliphate. Decolonisation and world order. London: Hurst and Company.

Zukin, S. (1996). The culture of cities. London: Blackwell. 